\title{
Pengendalian Kualitas Produksi Jalangkote (Studi Kasus: Produksi Jalangkote Berkah di Jalan Kartini, Kel. Lolu Selatan, Kec. Palu Timur, Kota Palu, Sulawesi Tengah)
}

\author{
Chalfin Lieputera Kaliongga $^{1}$, Fadjryani ${ }^{2}$, Eka Rizky Wulansari ${ }^{3}$ \\ Universitas Tadulako ${ }^{1,2,3}$ \\ Kota Palu, Sulawesi Tengah, Indonesia
}

\begin{abstract}
Nowdays, the business world demands companies to improve product quality by developing ideas to obtain effectively and efficiently to achieve targets and goals. Jalangkote Berkah is a form of business engaged in the manufacture of food preparations namely jalangkote. The purpose of this study was to study how to produce Jalangkote in Jalangkote Berkah, Kartini street, South Lolu, North Palu, Palu City, Central Sulawesi, depends on the quality of statistics so that they get the maximum benefit from the control. The method used in this study is Quality Control Statistics with the Six Sigma concept. Based on the results obtained in this study that the overall estimated value of production errors is 0.013 between the Statistical Control values with various UCL and LCL values calculating various amounts of production, then the data depends on statistical control, and the categories that must be of particular interest The size image is not suitable as seen from the Pareto diagram.
\end{abstract}

Keywords: jalangkote, production, defects, quality, control statistics, six sigma

\begin{abstract}
ABSTRAK
Dunia usaha sekarang menuntut perusahaan untuk lebih meningkatkan kualitas produk dengan mengembangkan ide-ide untuk memperoleh efektif dan efisien untuk mencapai sasaran dan tujuan. Toko Jalangkote Berkah merupakan bentuk usaha yang bergerak dibidang pembuatan olahan makanan yaitu jalangkote. Tujuan dari penelitian ini adalah untuk mengetahui apakah produksi Jalangkote di Jalangkote Berkah, Jl. Kartini, Lolu Selatan, Palu Utara, Kota Palu, Sulawesi Tengah, berada pada pengendalian kualitas statistik sehingga mendapat keuntungan yang maksimum dari pengendalian kesalahan tersebut. Metode yang digunakan pada penelitian ini ialah Statistic Quality Control dengan konsep Six Sigma. Adapun hasil yang diperoleh pada penelitian ini yaitu keseluruhan nilai proporsi kesalahan produksi yaitu sebesar 0.013 berada diantara nilai Control Statistic dengan nilai UCL dan LCL yang beragam akibat jumlah produksi yang beragam, maka data berada dalam statistika control, dan kategori kesalahan yang harus diberi perhatian khusus yaitu cacat ukuran tidak sesuai dilihat dari diagram pareto.
\end{abstract}

Kata kunci: jalangkote, produksi, cacat, kualitas, statistik kontrol, six sigma

\section{PENDAHULUAN}

Kualitas telah menjadi pertimbangan utama bagi konsumen untuk memenuhi kebutuhannya, hal ini karena pada era globalisasi seperti sekarang ini jumlah produk sejenis yang beredar di pasaran sangat banyak dan rata-rata produk 
tersebut memiliki harga dan fungsi dasar yang sama. Jadi, satu-satunya dimensi yang dapat digunakan untuk membedakan produk sejenis tersebut adalah kualitas produk tersebut. Untuk dapat bertahan di pasar yang kompetitif, peningkatan kualitas dan produktivitas proses atau produk merupakan suatu keharusan bagi setiap perusahaan (Runtuwene, 2017). Para pemilik bisnis berlomba-lomba untuk dapat menarik perhatian konsumen dengan cara memproduksi atau menghasilkan suatu produk yang berkualitas (Marire, 2014). Produk yang berkualitas baik akan mencerminkan keberhasilan suatu perusahaan dalam memenuhi harapan konsumen, yang tentunya akan membawa citra baik bagi produsen (Indriastitu, 2017).

Semakin meningkatnya kemajuan proses produksi makin diperlukan pengendalian kualitas. Kontrol kualitas sangat diperlukan dalam memproduksi suatu barang untuk menjaga kestabilan mutu. Tujuan pengendalian proses stastistik terutama adalah mengadakan pengurangan terhadap variasi atau kesalahan-kesalahan proses. Selain itu, tujuan utama pokok pengendalian kualitas statistik adalah menyelidiki dengan cepat terjadinya sebab-sebab terduga atau pergeseran proses sedemikian hingga penyelidikan terhadap proses itu, dan tindakan perbaikan dapat dilakukan sebelum terlalu banyak memproduksi unit yang tidak sesuai. Grafik pengendali adalah teknik pengendali proses pada jalur yang digunakan secara luas.

Setiap perusahan sangat memperhatikan kualitas produknya. setiap perusahan pada dasarnya selalu menjaga dan meningkatkan kualitas produknya agar selalu dapat memenuhi keinginan konsumen atau masyarakat.

Salah satu metode yang dapat digunakan oleh perusahaan dalam usaha pengendalian kualitas adalah Six Sigma. Metode ini digunakan untuk meminimalisir jumlah cacat (defect) dari sebuah produk sebagai upaya pengendalian kulitas prusahaan (Caesaron \& Tandianto, 2016).

Pada penelitian ini, penulis tertarik untuk melihat apakah produksi pembuatan jalangkote di Toko Jalangkote Berkah berada pada statistik kontrol yang baik selain itu sebagai bentuk pengawasan kepada pabrik dalam memproduksi jalangkote.

\section{TINJAUAN PUSTAKA DAN PENGEMBANGAN HIPOTESIS}

Salah satu metode yang dapat membantu perusahaan untuk mengendalikan kualitas proses produksinya adalah menggunakan Statistical Quality Control (SQC). Metode statistik sangat diperlukan untuk memahami variabilitas dalam variabel produk dan proses selain itu penggunaan metode statistic juga dapat meminimalkan variabilitas yang berpengaruh langsung terhadap kualitas produk (Alkubaisi, 2013).

Statistical Quality Control (SQC) merupakan teknik yang dikembangkan berdasarkan konsepsi mengenai variabilitas proses, yang secara luas diterapkan tidak hanya dalam proses manufaktur tetapi juga dalam operasi layanan jasa (Halim, 2014). SQC adalah alat yang efektif untuk pengendalian kualitas di semua jenis industri baik itu industri manufaktur ataupun di industri lainnya (Harpreet, 2016).

Apabila perusahaan mampu menerapkan metode SQC ini dengan benar, maka perusahaan akan mampu mencegah masalah, mengontrol proses produksi 
mereka, dan pada akhirnya meningkatkan keuntungan dan kepuasan pelanggan (Madanhire, 2016).

Penerapan metode SQC yang baik dan benar di dalam perusahaan dapat meningkatkan kinerja proses produksi serta mengurangi variabilitas produk dan meningkatkan efisiensi produksi dengan mengurangi pemborosan dan pengerjaan ulang (Mengesha, 2013).

\section{Kendali Proporsi (P-Chart)}

Data diambil dari beberapa proses pengolahan yang merupakan piranti yang berpengaruh langsung dan dianalisis secara berurutan dengan bagan kendali $\mathrm{P}$ untuk data atribut cacat. Penggunaan bagan kendali $\mathrm{P}$ terhadap jumlah cacatadalah sebagai berikut:

1) Menentukan ukuran contoh (k)

2) Menghitung nilai rata-rata produk yang cacat

3) Menghitung nilai simpangan baku

$$
\bar{p}=\frac{\text { Jumlah produk cacat }}{\text { jumlah sampel }}
$$

4) Menghitung batas kontrol

$$
\sqrt{\frac{P(1-p)}{n}}
$$

$$
\begin{aligned}
& U C L=p+3 \sqrt{\frac{P(1-p)}{n}} \\
& L C L=p-3 \sqrt{\frac{P(1-p)}{n}}
\end{aligned}
$$

Dengan :

$U C L=$ Upper Control Limit

$L C L=$ Lower Control Limit

$p \quad=$ Rata-Rata Proporsi Kecacatan

$n \quad=$ Jumlah Sampel

\section{Diagram Sebab Akibat}

Diagram sebab akibat digunakan untuk menganalisa persoalan dan faktorfaktor yang menyebabkan penyimpangan mutu (cacat) pada produksi. berikut :

Langkah-langkah untuk membuat diagram sebab akibat adalah sebagai

1. Identifikasi masalah serta dibuat sebagai pengaruh tulang punggung

2. Identifikasi kategori-kategori penyebab umum yang mungkin terjadi

3. Tambahkan cabang-cabang atau tulang-tulang pendukung kepada diagram yang menunjukan penyebab khusus.

\section{Metode Three-Sigma}

Three sigma adalah bertujuan yang hampir sempurna dalam memenuhi persyaratan pelanggan (Pande dan Cavanagh, 2002). Menurut Gaspersz (2005), three sigma adalah suatu visi peningkatan kualitas menuju target 3,4 kegagalan 
per sejuta kesempatan untuk setiap transaksi produk barang dan jasa. Jadi six sigma merupakan suatu metode atau teknik pengendalian dan peningkatan kualitas dramatic yang merupakan terobosan baru dalam bidang manajemen kualitas.

Terdapat enam aspek kunci yang perludiperhatikan dalam aplikasi konsep

Six Sigma, yaitu:

1. Identifikasi pelanggan

2. Identifikasi produk

3. Identifikasi kebutuhan dalam memproduksi produk untuk pelanggan

4. Definisi proses

5. Menghindari kesalahan dalam proses dan menghilangkan semua pemborosan yang ada

6. Tingkatkan proses secara terus menerus menuju target Three Sigma

Menurut Gaspersz (2005) apabila konsep Six Sigma akan ditetapkan dalam bidang manufakturing, terdapat enam aspek yang perlu diperhatikan yaitu:

1. Identifikasi karakteristik produk yang memuaskan pelanggan (sesuai kebutuhan dan ekspetasi pelanggan).

2. Mengklasifikasikan semua karakteristik kualitas itu sebagai CTQ (CriticalToQuality) individual.

3. Menentukan apakah setiap CTQ tersebut dapat dikendalikanmelalui pengendalian material, mesin proses kerja dan lain-lain.

4. Menentukan batas maksimum toleransi untuk setiap CTQ sesuai yang diinginkan pelanggn (menentukan nilai UCL dan LCL darisetiap CTQ)

\section{Implementasi Pendekatan Six-Sigma}

Metode yang digunakan mengacu pada prinsip-prinsip yang terdapat dalam metode Six Sigma. Metode ini digunakan untuk mengantisipasi terjadinya kesalahan atau defect dengan menggunakan langkah-langkah terukur dan terstruktur. Dengan berdasar pada data yang ada, maka Continuous improvement dapat dilakukan berdasar metodologi Six sigma yang meliputi DMAIC (Pete\& Holpp, 2002).

\section{A. Define}

Pada tahapan ini ditentukan proporsi defect yang menjadi penyebab paling signifikan terhadap adanya kerusakan yang merupakan sumber kegagalan produksi. Cara yang ditempuh adalah:

1. Mendefinisikan masalah standar kualitas dalam menghasilkan produk yang telah ditentukan perusahaan.

2. Mendefinisikan rencana tindakan yang harus dilakukan berdasarkan hasil observasi dan analisis penelitian.

3. Menetapkan sasaran dan tujuan peningkatan kualitas six sigma berdasarkan hasil observasi.

\section{B. Measure}

Tahap pengukuran dilakukan melalui 2 tahap dengan pengambilan sampel pada perusahaan perusahaan selama Desmeber 2011 sebagai berikut: 
1. Analisis diagram kontrol (U-Chart)

Diagram kontrol U digunakan untuk atribut yaitu pada sifat-sifat barang yang didasarkan atas proporsi jumlah suatu kejadian seperti diterima atau ditolak akibat proses produksi. Diagram ini dapat disusun dengan langkah sebagai berikut:

a) Pengambilan populasi dan sempel

b) Pemeriksaan karakteristik dengan menghitung nilai mean.

Rumus mencari nilai mean:

$p=\frac{\sum n p}{\sum n}$

Dimana :

$n=$ Jumlah Sampel

$n p=$ Jumlah Kecacatan

$p=$ Rata-Rata Proporsi Kecacatan

c) Menentukan batas kendali terhadap pengawasan yang dilakukan dengan menetapkan nilai UCL (Upper Control Limit / batas spesifikasi atas) dan LCL (Lower Control Limit / batas spesifikasi bawah).

$\begin{aligned} U C L & =p+3 \sqrt{\frac{p}{n}} \\ L C L & =p-3 \sqrt{\frac{p}{n}}\end{aligned}$

Dimana :

$U C L=$ Upper Control Limit

$L C L=$ Lower Control Limit

$p \quad=$ Rata-Rata Proporsi Kecacatan

$n \quad=$ Jumlah Sampel

\section{Improve}

Merupakan tahap peningkatan kualitas Six Sigma dengan melakukan pengukuran (lihat dari peluang, kerusakan, proses kapabilitas saat ini), rekomendasi ulasan perbaikan, menganalisa kemudian tindakan perbaikan dilakukan.

\section{Control}

Merupakan tahap peningkatan kualitas dengan memastikan level baru kinerja dalam kondisi standar dan terjaga nilai-nilai peningkatannya yang kemudian didokumentasikan dan disebarluaskan yang berguna sebagai langkah perbaikan untuk kinerja proses berikutnya.

\section{Analisis Faktor-Faktor Yang Menyebabkan Terjadinya Cacat Produk}

Kelemahan dan penyimpangan yang terjadi pada proses ditelusuri sebabsebabnya dengan menggunakan analisis diagram sebab akibat. Faktor-faktor yang memengaruhi kelemahan proses sehingga menimbulkan adanya produk cacat di antaranya ditelusuri dari mesin, karyawan, dan bahan baku. 


\section{METODE PENELITIAN}

\section{Populasi dan Sampel Penelitian}

Pada penelitian ini, populasinya adalah jumlah produksi seluruh usaha jalangkote di Kota Palu. Sampel yang diambil adalah jumlah produksi salah satu usaha jalangkote di Kota Palu yang bernama "Jalangkote Berkah" selama 20 hari (6 - 25 April 2020).

\section{Teknik Pengumpulan Data}

Data yang digunakan dalam penelitian ini adalah data primer. Data ini diperoleh dari wawancara langsung mengenai jumlah produksi jalangkote dan jumlah cacat tiap hari dalam 20 hari di Toko Jalangkote Berkah, Jalan Kartini, Kel. Lolu Selatan, Kec. Palu Utara, Kota Palu, Sulawesi Tengah.

\section{Analisis Data}

Analisis data yang digunakan pada penelitian ini dilakukan dengan menggunakan metode Six Sigma dengan menggunakan bantuan aplikasi Minitab. Tahapan analisis yang dilakukan adalah pendefinisian (define), pengukuran (measure), penganalisaan (analyze), perbaikan (improve), dan pengendalian (control).

\section{HASIL PENGUJIAN HIPOTESIS}

Three sigma sebagai salah satu alternatif dalam prinsip-prinsip pengendalian kualitas, dengan metode six sigma memungkinkan perusahaan melakukan peningkatan luar biasa dengan terobosan yang aktual. three sigma merupakan alat penting bagi manajemen produksi untuk menjaga, memperbaiki, mempertahankan kualitas produk dan terutama untuk mencapai peningkatan kualitas menuju zero defect. Dalam penelitian ini penerapan pengendalian kualitas yang digunakan adalah dengan metode Six Sigma yang melalui lima tahapan analisis yaitu define, measure, analyze, improve, dan control.

\section{Define}

Pada produksi Jalangkote Berkah terdapat 2 jenis cacat yang didefinisikan sebagai Critical to Qulaity (CTQ). Untuk jenis cacat yang digunakan dapat dilihat seperti table dibawah ini.

Tabel 1. Statistika Deskriptif

\begin{tabular}{|l|l|}
\hline \multicolumn{1}{|c|}{ Jenis Cacat } & \multicolumn{1}{|c|}{ Keterangan } \\
\hline Ukuran Tidak Sesuai (A) & $\begin{array}{l}\text { Ukuran atau bentuk jalangkote tidak } \\
\text { sesuai dengan standar yang telah } \\
\text { ditetapkann oleh produsen. }\end{array}$ \\
\hline Overcook (B) & $\begin{array}{l}\text { Terdapat jalangkote yang tingkat } \\
\text { kematangannya lebih dari yang telah } \\
\text { ditetapkan. }\end{array}$ \\
\hline
\end{tabular}

Berikut hasil pengamatan yang dilakukan dalam 20 hari pengamatan dapat dilihat pada tabel di bawah ini. 
Tabel 2. Rata-Rata Proporsi Produksi Cacat

\begin{tabular}{|c|c|c|c|c|c|c|}
\hline \multirow{2}{*}{$\begin{array}{l}\text { Hari } \\
\text { ke- }\end{array}$} & \multirow{2}{*}{$\begin{array}{l}\text { Tanggal } \\
\text { Produksi }\end{array}$} & \multirow{2}{*}{$\begin{array}{c}\text { Jumlah } \\
\text { Produksi (n) }\end{array}$} & \multicolumn{2}{|c|}{ Jenis Cacat } & \multirow{2}{*}{$\begin{array}{c}\text { Jumlah } \\
\text { Cacat } \\
(\mathbf{x})\end{array}$} & \multirow{2}{*}{$\begin{array}{c}\text { Proporsi } \\
(\mathbf{x} / \mathbf{n})\end{array}$} \\
\hline & & & $\mathrm{A}$ & $\mathrm{B}$ & & \\
\hline 1 & 06-Apr-20 & 120 & 1 & 1 & 2 & 0,02 \\
\hline 2 & 07-Apr-20 & 120 & 1 & 0 & 1 & 0,01 \\
\hline 3 & 08-Apr-20 & 123 & 1 & 0 & 1 & 0,01 \\
\hline 4 & 09-Apr-20 & 125 & 2 & 0 & 2 & 0,02 \\
\hline 5 & $10-A p r-20$ & 118 & 2 & 1 & 3 & 0,03 \\
\hline 6 & 11-Apr-20 & 92 & 2 & 0 & 2 & 0,02 \\
\hline 7 & 12-Apr-20 & 130 & 2 & 1 & 3 & 0,02 \\
\hline 8 & 13-Apr-20 & 135 & 1 & 0 & 1 & 0,01 \\
\hline 9 & 14-Apr-20 & 128 & 2 & 0 & 2 & 0,02 \\
\hline 10 & 15-Apr-20 & 145 & 1 & 0 & 1 & 0,01 \\
\hline 11 & 16-Apr-20 & 130 & 2 & 0 & 2 & 0,02 \\
\hline 12 & 17-Apr-20 & 110 & 1 & 0 & 1 & 0,01 \\
\hline 13 & 18-Apr-20 & 190 & 0 & 1 & 1 & 0,01 \\
\hline 14 & 19-Apr-20 & 150 & 1 & 1 & 2 & 0,01 \\
\hline 15 & 20-Apr-20 & 180 & 1 & 0 & 1 & 0,01 \\
\hline 16 & 21-Apr-20 & 197 & 2 & 1 & 3 & 0,02 \\
\hline 17 & 22-Apr-20 & 245 & 3 & 2 & 5 & 0,02 \\
\hline 18 & 23-Apr-20 & 137 & 2 & 1 & 3 & 0,02 \\
\hline 19 & 24-Apr-20 & 224 & 3 & 0 & 3 & 0,01 \\
\hline 20 & 25-Apr-20 & 185 & 2 & 0 & 2 & 0,01 \\
\hline
\end{tabular}

Dari tabel di atas, dapat dilihat bahwa proporsi produksi jalangkote yang cacat paling besar yaitu pada pengamatan hari ke-5 dengan proporsi produk gagal sebesar 0.03 .

\section{Measure}

Dari data tersebut didapatkan bahwa jumlah produk gagal dalam 20 hari pengamatan adalah sebanyak 41 dari 2984 jalangkote yang diproduksi. Dari datadata tersebut kita dapat membuat sebuah peta kendali dengan melakukan perhitungan seperti di bawah ini :

a. Menghitung Center Line dari proporsi produk jalangkote yang gagal produksi dengan menggunakan rumus

$$
\begin{aligned}
& p=\frac{\sum n p}{\sum n} \\
& p=\frac{41}{2984} \\
& p=0,013
\end{aligned}
$$


b. Menghitung proporsi kerusakan untuk setiap hari pengamatan dengan menggunakan rumus

$p=\frac{x_{i}}{n}$

Pada pengamatan hari pertama :

$p=\frac{2}{120}$

$p=0,01$

Pada pengamatan hari kedua :

$p=\frac{1}{120}$

$p=0,008$

Keterangan : Untuk pengamatan hari seterusnya menggunakan rumus seperti di atas.

c. Menghitung batas kendali atas atau Upper Control Limit (UCL) dengan menggunakan rumus

$U C L=\mathrm{p}+3 \sqrt{\frac{p}{n}}$

Untuk pengamatan hari pertama :

$U C L=0,013+3 \sqrt{\frac{0,013}{120}}$

$U C L=0,013+3 \sqrt{0,000108}$

$U C L=0,013+3(0,010408)$

$U C L=0,013+0,031225$

$U C L=0,044225$

Keterangan : Untuk pengamatan hari kedua dan seterusnya menggunakan rumus seperti di atas.

d. Menghitung batas kendali bawah atau Lower Conterdasarrol Limit (LCL) dengan menggunakan rumus

$L C L=p-3 \sqrt{\frac{p}{n}}$

Untuk pengamatan hari pertama :

$L C L=0,03-3 \sqrt{0,000108}$

$L C L=0,03-3(0,010408)$

$L C L=0,03-0,031225$

$L C L=-0,01822 \approx 0$

Keterangan : Untuk pengamatan hari kedua dan seterusnya menggunakan rumus seperti di atas.

Berikut merupakan hasil perhitungan batas peta kendali : 
Tabel 3. Batas Peta Kendali

\begin{tabular}{|c|c|c|c|c|c|c|}
\hline $\begin{array}{c}\text { Hari } \\
\text { ke- }\end{array}$ & Total Produksi & Rusak & $\mathrm{u}$ & $\mathrm{u}$ bar & $\mathrm{UCL}$ & $\mathrm{LCL}$ \\
\hline 1 & 120 & 2 & 0,02 & 0,01374 & 0,04584 & $-0,0184$ \\
\hline 2 & 120 & 1 & 0,01 & 0,01374 & 0,04584 & $-0,0184$ \\
\hline 3 & 123 & 1 & 0,01 & 0,01374 & 0,04545 & $-0,018$ \\
\hline 4 & 125 & 2 & 0,02 & 0,01374 & 0,04519 & $-0,0177$ \\
\hline 5 & 118 & 3 & 0,03 & 0,01374 & 0,04611 & $-0,0186$ \\
\hline 6 & 92 & 2 & 0,02 & 0,01374 & 0,0504 & $-0,0229$ \\
\hline 7 & 130 & 3 & 0,02 & 0,01374 & 0,04458 & $-0,0171$ \\
\hline 8 & 135 & 1 & 0,01 & 0,01374 & 0,04401 & $-0,0165$ \\
\hline 9 & 128 & 2 & 0,02 & 0,01374 & 0,04482 & $-0,0173$ \\
\hline 10 & 145 & 1 & 0,01 & 0,01374 & 0,04294 & $-0,0155$ \\
\hline 11 & 130 & 2 & 0,02 & 0,01374 & 0,04458 & $-0,0171$ \\
\hline 12 & 110 & 1 & 0,01 & 0,01374 & 0,04727 & $-0,0198$ \\
\hline 13 & 190 & 1 & 0,01 & 0,01374 & 0,03925 & $-0,0118$ \\
\hline 14 & 150 & 2 & 0,01 & 0,01374 & 0,04245 & $-0,015$ \\
\hline 15 & 180 & 1 & 0,01 & 0,01374 & 0,03995 & $-0,0125$ \\
\hline 16 & 197 & 3 & 0,02 & 0,01374 & 0,03879 & $-0,0113$ \\
\hline 17 & 245 & 5 & 0,02 & 0,01374 & 0,03621 & $-0,0087$ \\
\hline 18 & 137 & 3 & 0,02 & 0,01374 & 0,04378 & $-0,0163$ \\
\hline 19 & 224 & 3 & 0,01 & 0,01374 & 0,03724 & $-0,0098$ \\
\hline 20 & 185 & 2 & 0,01 & 0,01374 & 0,03959 & $-0,0121$ \\
\hline & & & & & & \\
\hline
\end{tabular}

Berikut ini adalah peta kendali proporsi kesalahan (Control U-Chart) :

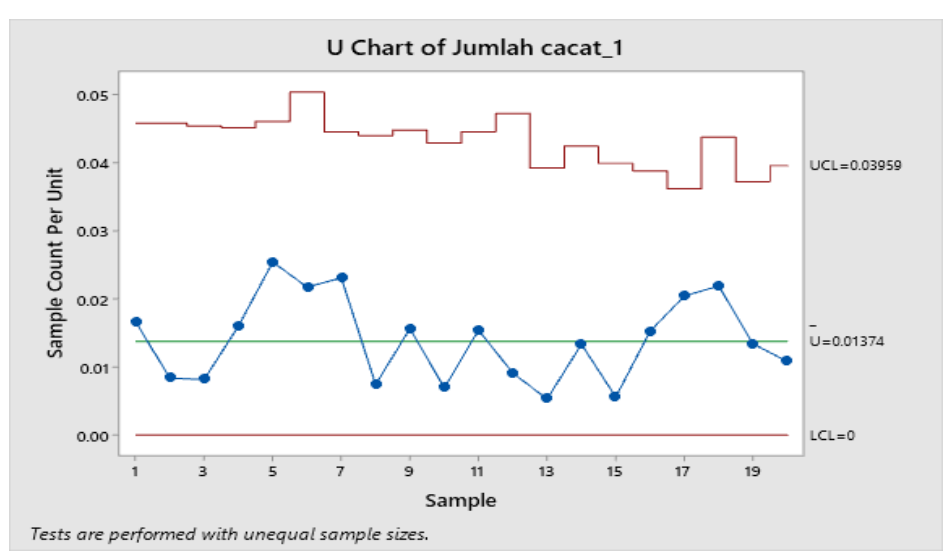

Gambar 1. Control U-Chart

Berdasarkan grafis yang dihasilkan dari pengolahan dengan software minitab 2019, memberikan informasi bahwa nilai batas kendali atas (UCL) sebesar 0.03959, rata-rata U sebesar 0.01374 dan nilai batas kendali bawah (LCL) 
sebesar 0.0. maka dari grafik diatas dapat disimpulkan bahwa proses produksi jalangkote berada dalam kendali.

\section{Analyze}

Pada tahap ini dilakukan analisis diagram pareto berdasarkan data yang telah diolah untuk mengatahui presentase jenis produk cacat dan urutan jenis kerusakan yang terjadi dari yang tertinggi hingga yang terendah pada produksi jalangkote di Toko Usaha Jalangkote Berkah. Berikut gambar diagram pareto yang dihasilkan :

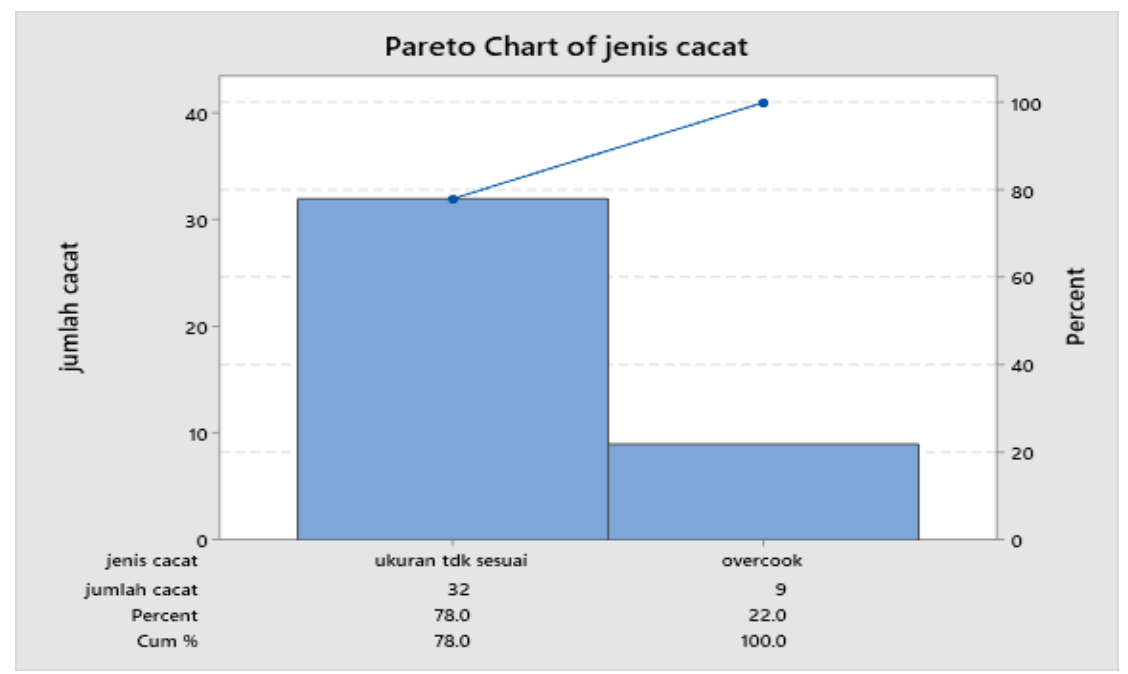

\section{Gambar 2. Diagram Pareto}

Dari diagram pareto di atas dapat di ketahui bahwa $78 \%$ cacat pada ukuran tidak sesuai dan $22 \%$ cacat pada overcook. Sehingga produsen Jalangkote harus lebih memperhatikan kesalahan-kesalahan yang berhubungan dengan ukuran jalangkote.

\section{Improve}

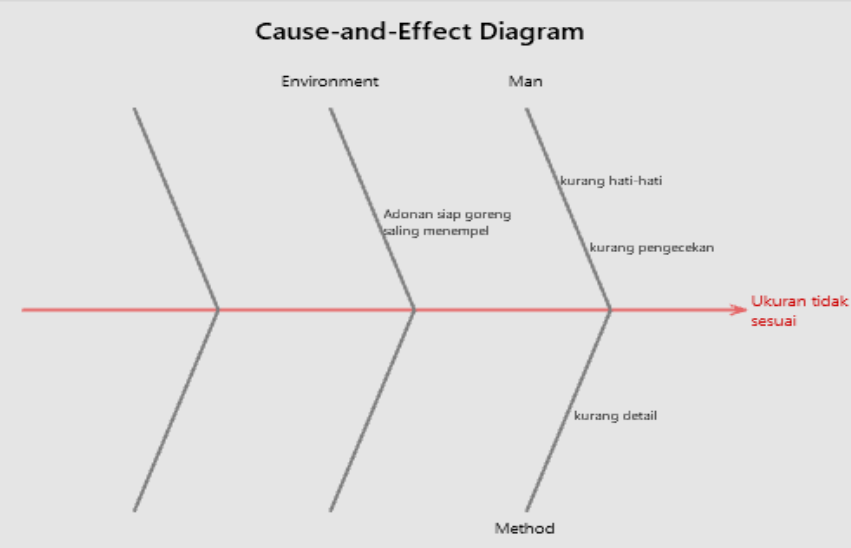

Gambar 3. Bagan Sebab Akibat Ukuran Tidak Sesuai 


\begin{tabular}{|l|l|l|}
\hline Man & Method & Environment \\
\hline kurang hati-hati & kurang detail & $\begin{array}{l}\text { adonan siap goreng saling } \\
\text { menempel }\end{array}$ \\
\hline $\begin{array}{l}\text { kurang } \\
\text { pengecekan }\end{array}$ & & \\
\hline
\end{tabular}



Gambar 4. Bagan Sebab Akibat Overcook

\begin{tabular}{|l|l|l|}
\hline Man & Method & Environment \\
\hline kurang focus & kurang detail & $\begin{array}{l}\text { Suhu Minyak terlalu } \\
\text { panas }\end{array}$ \\
\hline $\begin{array}{l}\text { kurang mengecek } \\
\text { waktu }\end{array}$ & \\
\hline
\end{tabular}

\section{KESIMPULAN, KETERBATASAN DAN SARAN} berikut:

Kesimpulan yang didapatkan dari hasil penelitian ini adalah sebagai

1. Proporsi kerusakan dari produksi Jalangkote menunjukkan angka yang kecil sehingga dapat dikatakan bahwa kerugian akan kegagalan produk ini tidak mempengaruhi keuntungan.

2. Nilai-nilai proporsi produk cacat berada diantara nilai batas kendali atas (UCL) dan batas kendali bawah (LCL) menujukkan bahwa nilai-nilai kesalahan tersebut masih masuk dalam kontrol statistik. Sehingga terdapat toleransi akan kesalahan.

3. Kecacatan produk yang paling tinggi ialah bentuk produk tidak sesuai, sehingga produsen harus lebih memperhatikan bagaimana kualitas pembentukan jalangkote, serta melakukan pengecekan sebelum melakukan penggorengan sehingga dapat mengurangi produk yang cacat.

Saran yang dapat peneliti berikan kepada pemilik Jalangkote Berkah, yaitu dalam produksi jalangkoteteliti dalam pemilihan variabel-variabel pada sebab akibat (cause and effect) 


\section{REFERENCES}

Alkubaisi, M. 2013. Statistical Quality Control (Sqc) And Six Sigma Methodology: An Application Of X-Bar Chart On Kuwait Petroleum Company. International Journal Of Business Administration, 4(3).

Dino Caesaron, Tandianto. 2017. Penerapan Metode Six Sigma Dengan Pendekatan DMAIC Pada Proses Handlin Painted Body BMW X3 (Studi Kasus PT Tjahja Sakti Motor). Jurna Pasti Vol. 9 No.3: 248-256.

Gasperz, Vincent. 2005. Total Quality Management. Jakarta: PT. Gramedia Pustaka Utama.

Gasperz, Vincent. 2007. Lean Six Sigma. Jakarta: PT. Gramedia Pustaka Utama.

Halim, Abdul. 2014. Manajemen Keuangan Sektor Publik Probematika Penerimaan Dan Pengeluaran Pemerintah. Jakarta: Selemba Empat.

Harpreet, E., Oberoi, S., Parmar, M., Kaur, H., \& Mehra, R. 2016. Spc (Statistical Process Control ): A Quality Control Technique For Confirmation To Ability Of Process. International Research Journal Of Engineering And Technology, 3(6): 666-672.

Indriastuti, A., \& Nafiah, Z. 2017. Pengaruh Volume Perdagangan, Kurs dan Risiko Pasar terhadap Return Saham. Jurnal STIE Semarang, 9(1): 57-66.

Madanhire, I., \& Mbohwa, C. 2016. Application Of Statistical Process Control (Spc) In Manufacturing Industry In A Developing Country. Procedia Cirp, 40: 580-583.

Marire, M. I., Ekpere, B., \& Ngozi, N. 2014. The Problems Of Quality Control In The Manufacturing Sector A Study Of Nigeria Breweries Plc, Enugu. Iosr Journal Of Business And Management, 16(12, 2278-387X): 96-107.

Mengesha, Y., Singh, A. P., \& Yimer, W. 2013. Yonatan Mengesha WassihunYimer Quality Improvement Using Statistical Process Control Tools In Glass Bottles Manufacturing. International Journal for Quality Research, 7(October 2012): 107-126.

Pande, Neumann, Roland R.Cavanagh. 2002. The Six sigma Way Bagaimana GE, Motorola \& Perusahaan Terkenal Lainnya Mengasah Kinerja Mereka. Yogjakarta : ANDI.

Pete \& Holpp. 2002. What Is Six Sigma. Yogjakarta : ANDI.

Runtuwene, V. E., Massie, J. D. D., \& Tumewu, F. (N.D.). 2017. Statistik Di Pt.Massindo Sinar Pratama Manado Quality Control Analysis Using Statistical Quality Control. Jakarta: Pt Massindo, 5(2): 2516-2525 